\title{
JUURNAL.RU
}

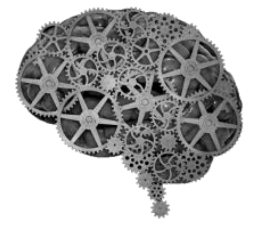

COMPANY GROUP "INTELLEKT"

\author{
Никитина Н.С. \\ МБУЗ городская больница № 2 \\ Новочеркасск, Россия
}

doi: 10.18411/lj2016-6-3-03

\section{Риносинусогенная головная и лицевая боль в практике врача - невролога}

Воспалительные заболевания околоносовых пазух нередко сопровождаются болевыми ощущениями - головной и лицевой болью.

Вопреки распространенным представлениям, головная боль (ГБ) при синуситах встречается нечасто. У большинства больных с симметричной двусторонней болью в лобной, височной, а иногда и с вовлечением затылочной области, при прицельном обследовании выявляется тензионная ГБ (ГБ напряжения) [1].

Классификация международного общества головной боли рассматривает в качестве возможных причин ГБ только острый фронтит и сфеноидит, подчеркивая, что участие хронического синусита вне обострения в возникновении ГБ не доказано [2].

Лицевые боли - прозопалгии могут быть вызваны самыми разнообразными патологическими процессами. Боли в области лица наблюдаются при невритах и невралгиях чувствительных нервов, при ганглионевритах, при заболеваниях зубов, глаза, ЛОР органов $[3,4,5,6,7]$, в ряде случаев возникают боли сосудистого происхождения, артрогенные, вертеброгенные, психогенные и отраженные.

Нередко больные с прозопалгиями оказываются предметом диагностических дискуссий ЛОР врачей и неврологов, причем зачастую 
складывается ситуация, когда оториноларинголог выставляет диагноз «невралгия тройничного нерва», а невролог настаивает на наличии у больного хронического синусита. Действительно, установить причину возникновения лицевых болей или их связь с заболеваниями ЛОР органов бывает сложно. С одной стороны, лицевые боли могут быть единственным клиническим признаком параназального синусита, а другие проявления (затрудненное носовое дыхание, выделения из носа) могут отсутствовать. В этих случаях и рентгенологическое исследование больного не всегда может помочь диагностике, поскольку возможна клинико-рентгенологическая диссоциация, при которой даже при наличии гнойного экссудата в пазухе она выглядит на рентгенограмме интактной.

С другой стороны, при невралгии тройничного нерва (НТН) возможно появление постоянных «фоновых» тупых болей между приступами, что может привести к ошибочному заключению о наличии у больного синусита. Вероятность диагностической ошибки такого плана увеличивается при выраженности вегетативных нарушений, характерных для НТН: слезотечения, ринореи, гиперемии кожи и конъюнктивы, отечности кожи лица на стороне поражения, отека слизистой оболочки соответствующей половины носа и околоносовых пазух, что вызывает снижение их рентгенологической прозрачности.

Отек слизистой оболочки полости носа и пазух и увеличение ее секреции при НТН могут быть объяснены с точки зрения теории «нейрогенного воспаления» $[6,8]$. По современным представлениям асептическое нейрогенное периваскулярное воспаление как результат процесса локального высвобождения из периферических нервных окончаний нейропептидов является значимым для сенситизации нервных окончаний при ответе на нормальные физиологические стимулы, а также для продолжения боли после уже завершившегося раздражения. В экспериментах было показано, что стимуляция чувствительных нейронов тройничного нерва вызывает экстравазацию белков плазмы, агрегацию 
тромбоцитов, активацию эндотелия и приводит к воспалению мягких тканей, сохраняющемуся от нескольких минут до нескольких часов.

Заболевания носа и околоносовых пазух, особенно воспалительного характера, сопровождаются многообразными болевыми ощущениями, как в проекции пазух, так и в зонах иррадиации.

Болевой синдром при синуситах имеет сложную природу и является следствием раздражения окончаний тройничного нерва в слизистой оболочке пазух продуктами метаболизма микроорганизмов и медиаторами воспаления, повышения давления экссудата в просвете пазухи при затруднении оттока, болезненной пульсации в результате избыточного пульсового растяжения артерий. Лицевая боль может быть вызвана нарушением вентиляционной функции соустий околоносовых пазух - это так называемая вакуумная или «утренняя» боль, возникающая вследствие понижения давления из-за резорбции воздуха. В ряде случаев боль в области верхнечелюстной пазухи может носить идиопатический характер.

Заболевания ЛОР органов могут стать причиной возникновения неврогенных прозопалгий $[8,9]$. К этой группе можно отнести невралгию тройничного нерва, ганглионеврит крылонебного узла (синдром Sluder), невралгию носоресничного нерва (синдром Charlin), глоссофарингеальную форму глоссодинии (синдром Sicard). Вовлечение в патологический процесс узла тройничного нерва (гассерова узла) возможно и при гнойном воспалении полостей среднего уха с распространением его на пирамиду височной кости. В таких случаях развивается синдром Градениго, который складывается из резкой боли в области глазницы, лобно-теменной области с иррадиацией в одноименную половину лица и зубы, пареза или паралича VI пары черепных нервов, гипостезии в зоне I ветви тройничного нерва со снижением или выпадением корнеального рефлекса на стороне поражения. 
Каждая форма прозопалгии имеет четко очерченные клинические характеристики. Для дифференциальной диагностики различных форм риносинусогенных прозопалгий может быть использован следующий алгоритм:

1. Анализ характера боли (исходная локализация, зона иррадиации и «рисунок» боли, характер боли, ее интенсивность, продолжительность и особенности приступа, провоцирующие факторы, наличие «курковых» зон, вегетативно-эффекторные нарушения, эффективность болеутоляющих, противосудорожных средств) для выявления признаков ноцицептивной или нейропатической боли.

2. Тщательный осмотр ЛОР органов с анемизацией слизистой оболочки слизистой носа и при необходимости - анестезией зон проекции крылонебного и носо-ресничного узлов.

3. Компьютерная томография околоносовых пазух. 


\section{Литература:}

1. Бойко Н.В., Стагниева И.В. Дифференциальная диагностика ли-цевых болей. Рос. ринология. 2012. Т. 20. № 1. С. 39-42.

2. Стагниева И.В., Бойко Н.В. Головная и лицевая боль при риносинусите. Мед. вестник Юга России. 2014. № 3 С. 55-59.

3. Бойко Н.В., Банников С.А. Неинвазивный микоз околоносовых пазух. Рос. ринология. 2010. Т. 18. № 2. С. 39-41.

4. Бойко Н.В., Банников С.А., Колесников В.Н. Изолированные и сочетанные микозы полости носа и околоносовыз пазух. Рос. ринология. 2011. T.19. № 2. C. 8.

5. Стагниева И.В., Симбирцев А.С. Роль цитокинов в патогенезе лице-вой боли при риносинусите. Медицинская иммунология. 2015. Т. 17. № S. C. 319.

6. Стагниева И.В. Роль субстанции Р в патогенезе лицевой боли при риносинусите. Рос. ринология. 2015. Т. 23. № 1. С. 33-35.

7. Бойко Н.В., Панченко С.Н., Кириченко Ю.Г. К вопросу о морфогенезе инвертированной папилломы носа Российская ринология. 2008. Т. 16. № 3. C. $23-28$

8. Стагниева И.В., Симбирцев А.С. Определение роли субстанции Р и болевого симптома в диагностике иммунных нарушений при риносинусите. Иммунология 2015; 36 (5): 295-300.

9. Стагниева И.В. Лечение лицевой боли при риносинусите. Мед. вестник Юга России. 2015. № 1. С. 82-85. 